\title{
Children and youth in the context of international mobility patterns in Mexico
}

\author{
Edith Y. Gutiérrez Vázquez* \\ Silvia E. Giorguli Saucedo**
}

Recepción: 3 de noviembre de 2017 Aceptación: 29 de enero de 2018

Abstract In recent decades the patterns of international mobility in Mexico have consolidated. Emigration to the United States, the growing presence of women and children in the flow and the loss of circularity persist. At the same time, new patterns have emerged. There is evidence of a significantly large new flow of Mexicans and children of Mexicans born in US entering the country after having lived abroad. Within these heterogeneous patterns of mobility, we explore the extent to which minors in Mexico are exposed to international mobility either through their own migration experience or that of their parents or other relatives. In addition, we explore whether the educational and labor trajectories of adolescents vary depending on their exposure to international migration. Using information from the ten percent sample of the 2010 Mexican Census, we analyze the sociodemographic and geographic characteristics of these children. We also consider how family arrangements, especially co-residence of children with parents, mediate the effects of international migration on the children's well-being. Our results suggest international migration is linked to the absence of one (mainly the father) or both parents in all cases. In addition, enrollment in school and the labor status of children also vary depending on their exposure to international migration. For Mexican returnees and other immigrants, the probabilities of staying in school and out of work are notoriously lower. This relation is clearly mediated by the type of family arrangement.

KEY WORDS: international migration, educational attainment and labor market participation, children and youth, family arrangements, Mexico.

\footnotetext{
* Researcher and lecturer at the Departamento de Estudios Regionales-Ineser, Centro Universitario de Ciencias Económico Administrativas, Universidad de Guadalajara, edith.gutierrez@cucea.udg.mx

* President of El Colegio de México, sgiorguli@colmex.mx
} 


\section{Niños y jóvenes en el contexto de los patrones de movilidad internacional en México}

Resumen En décadas recientes, los patrones migratorios en México se han consolidado. La emigración a Estados Unidos, la creciente presencia de mujeres y niños en el flujo migratorio y la pérdida de circularidad persisten. A la par, han emergido nuevos patrones. Existe evidencia de mayor retorno de niños mexicanos nacidos en ambos lados de la frontera a México. En este contexto de movilidad internacional heterogénea, exploramos cómo los niños están expuestos de distintas maneras a movilidad internacional ya sea por experiencia propia (directa) o por la experiencia de algún miembro del hogar (indirecta). Adicionalmente analizamos si existen variaciones en las trayectorias educativas y laborales de los adolescentes dependiendo de su exposición a la migración. Utilizamos los microdatos de la muestra censal de 2010 para analizar las características demográficas de estos niños, también consideramos cómo los arreglos familiares, en especial la corresidencia con los padres, median los efectos de la migración internacional sobre el bienestar de los niños. Nuestros resultados sugieren que la migración internacional está vinculada con la ausencia de uno (comúnmente el padre) o ambos padres. También encontramos que la asistencia escolar y la participación en el mercado laboral varían dependiendo de la exposición que los adolescentes tienen al fenómeno migratorio. Los retornados mexicanos y los inmigrantes de otros países tienen notoriamente menores probabilidades de asistencia escolar y de permanecer fuera del mercado laboral. Aún más, encontramos que este tipo de relaciones están mediadas por el tipo de arreglo familiar en el que los adolescentes viven.

PALABRAS CLAVE: migración internacional, asistencia escolar y participación laboral, niños y jóvenes, arreglos familiares, México.

A sharp increase in Mexico-U.S. migration flows during the nineties and the first half of the last decade, together with an increase in the length of time these international migrants stay in U.S. and the loss of circularity in their travels, have shifted the discussion about the implications of this migration system for the communities and regions of origin. An increase in the permanent settlement of Mexicans in the United States and longer spans of family separation have encouraged a research agenda in Mexico interested in the effects of family disruption, and the emotional and noneconomic costs of migration for migrants and their families (among others, see Ariza \& 
D'Aubeterre, 2009, López Castro, 2007). At the same time, women and children have been increasingly exposed to some kind of mobility, either as migrants themselves or, in the case of children, through the migration of their parents, close relatives and friends. It is possible that the new family arrangements, the longer absence of fathers and mothers who have migrated, changes in household income when remittances are sent and the participation of the children of migrants in the flows themselves-probably a rite of passage during their adolescence-influence different aspects of the lives of those children in Mexico, who are exposed, one way or another, to international migration.

Previous research into international migration and education in Mexico has explored the link between the household migration experience and remittances, and educational attainment (Meza \& Pederzini, 2009; Hanson \& Woodruff, 2003; Giorguli \& Serratos, 2009; Antman, 2008; Borraz, 2005; McKenzie \& Rapoport, 2006). Even though the evidence is not conclusive, there are some consistent results to show that children living in communities with a high prevalence of migration tend to leave school earlier (Kandel \& Massey, 2002; Giorguli, Vargas, Ulloa, Hubert, \& Potter, 2010; Gutierrez, Sanchez, \& Giorguli, 2011). This line of research has mainly focused on the children who have stayed behind, and are exposed to international migration either through the migration of a household member, the support of remittances, or the migration experience of others in the communities of origin. However, a recent change in the migration profiles in Mexico suggests that the young population exposed to international migration has become more heterogeneous (Giorguli \& Gutierrez, 2011). Firstly because there has been an increase of return migration to Mexico (Zenteno, 2012). In some cases, this flow involves parents and their children. In fact, there are a large number of children born in the United States who have moved to Mexico during the last five years (more than half a million as shown in Table 1). The data from the 2010 Mexican census also shows an increase in the number of return migrants aged below 19 years.

Secondly, Mexico is considered a country of destination and transit for a number of migrants in their attempt to reach the U.S. Although they are still a small proportion of all migrants, the number of immigrants to Mexico has increased in the last decade (Castillo, 2012). In the case of young populations, there are a small number of children born outside Mexico who are also exposed to different migration experiences, basically related to their countries of origin. We can expect that these young migrants, many of whom are from Central America (about 20\% of the group in the category of "other migrants"), will most often be undocumented and living in families with an unstable economic situation. Thus, they will face more difficulties trying to integrate into the Mexican school system and stay enrolled, and they will probably enter earlier into the labor market. 


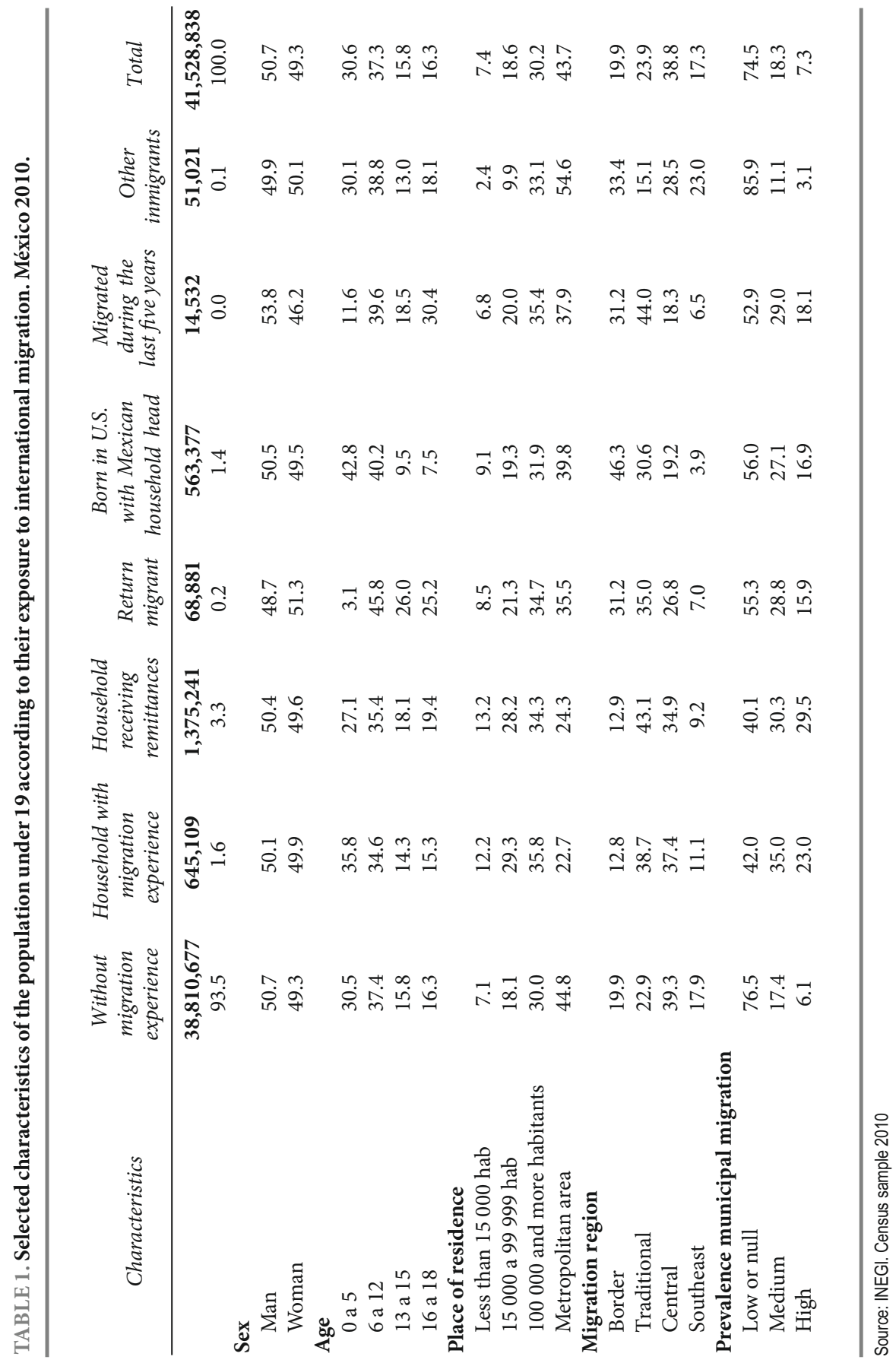


In this paper, we analyze the living conditions and family arrangements of all these different populations of children exposed to international migration. We also look at how they fare, whether they attend school or have entered early into the labor market. Specifically, we first describe the different groups of population 18 years old and younger marked by their link to international migration. Then, we move to analyze co-residence with their parents, school enrollment and their labor status. We use the 2010 Mexican Census Sample, which is a large representative sample that has assembled information for more than ten percent of the Mexican population. The large size of the sample allows us to estimate robust models of the enrollment and labor status of these populations.

We hypothesize that their family situation defines, to a large extent, the possible impacts of international migration on the educational opportunities of the young people involved. It has been documented that the family context-specifically coresidence with one or both parents-defines the learning environment and the resources available to children, and influences their educational trajectories (Giorguli, 2006). For our specific research interest, we explore whether the family arrangement mediates the potentially positive or negative effects of international migration on the lives of children. The Census allows us to explore whether the children are living with their mothers and fathers. We first look at different co-residence statuses by migration group and then estimate to what extent the effect of the family arrangement and the exposure to migration at the municipal level vary for each of the subpopulations analyzed. We also hypothesize that the separation from both parents will specifically have a larger negative effect on the probabilities of staying in school and out of the labor force. As the effects are different for girls and boys, our analysis is conducted separately for each sex.

\section{Family reorganization and international mobility in Mexico}

The traditional male migration to the U.S. was linked to a temporary reorganization of the household while the husband was away. Either wives would adopt the role of head of the household and remain in nuclear households, taking decisions on the distribution of resources and the education of the children, or else they would move, taking their children with them, to the household of their parents, or move in with their in-laws while the husband was away. This last form of rearrangement of the household implied more supervision over the wives and the lives of the children, and in some cases, less opportunity for the wives to participate in decisions on how to use the resources received from abroad (Arias, 2013; Hondagneu-Sotelo, 1994). Thus in this type of flow, when the wives "stayed behind", their negotiations would either 
empower them in terms of household decision taking (and make them the head of the household) or their gender role would not be greatly changed (and they would stay under the supervision of other family members) (Oehmichen, 2000; Giorguli, 2006).

As migration flows became more heterogeneous, the families' responses to migration also changed. We now expect to find a greater diversity of arrangements, including transnational families with members living on both sides of the border. Among the changes that have been documented recently are an increase in the number of separations or divorces that result in the formation of new households and also lead to an increase in the number of single parent households; the incorporation of women into the flow which has resulted in "doughnut households", where children remain with their grandparents and both parents are absent; and the formation of mixed households with some children born in Mexico and some children born in the U.S. (Arias, 2013).

Within the context of recent trends in the international mobility between Mexico and the U.S., it is also possible to consider that the returnees will either form new independent households in Mexico with all members moving back from abroad or they may move into extended households with relatives living in Mexico. The new family organization may also be the result of a family separation, in which case, we may see an increase in children living with one parent in the case of returnees or in the case of those who were born in the U.S. and migrated to Mexico with their parents.

In most cases, the international mobility of the children and their parents, or other relatives, may be linked to a reorganization of the composition of the household. The ways in which children respond and adapt to the changing context of their family due to the international mobility of the household members are mediated by the family's reorganization.

\section{The link between exposure to international migration and educational trajectories}

In most of the research conducted on education and migration, there has been an emphasis on how, in the communities of origin, family monetary resources, and especially resources invested in the children's education, change with the international migration of an adult member-usually the father. Within most of this literature, remittances are assumed to have a potentially positive effect on the enrollment of children as they allow greater resources to be invested in education and may release adolescent children from the need to enter the labor force at an early age. Thus, receiving remittances may delay leaving school and entering the labor force. So far, the evidence of empirical research conducted in Mexico is still inconclusive. Canales and Montiel (2005), for example, proved that households receiving remittances spend 
about the same proportion of their income on education compared to other households-whatever their socioeconomic status. Borraz (2005) found that factors such as the place of residence or the educational attainment of the mother may mediate this potential effect; on the basis of his results there would be some evidence that children in the poorest households, in rural settings or whose mothers have little education have the potential to benefit more from the increase of resources via remittances.

As we review the literature on the research conducted in Mexico we found studies that suggest a positive impact from remittances (Antman, 2012; Hanson \& Woodruff, 2003), with others that are more cautious and less optimistic regarding this effect (Giorguli \& Serratos, 2009; Meza \& Pederzini, 2009). Furthermore, some of the studies even suggest a negative relation between exposure to international migration and educational attainment at the community level (Kandel \& Massey, 2002; Giorguli \& Serratos, 2009; Gutierrez et al., 2011). If any conclusion can be drawn from prior research is that we need to study more comprehensively the interaction between international migration and the educational trajectories of children, and to build an analytical framework that allows us to disentangle the different dimensions in this interaction. As much of the literature has concentrated on economic explanations (basically, the resources invested in education), other factors such as changes in the learning environment, adult supervision of school work, the emotional distress related to family separation or to the arrival in a new place, have been overlooked.

In this paper we analyze several dimensions:

1. If international migration changes the resources available for investing in education thus delaying the entry of adolescent children into the labor force, those children in households receiving remittances will have higher enrollment rates and lower labor participation.

2. To the extent that international migration may disrupt the dynamics of the family, adult supervision, and the social capital of children remaining behind, we may expect that those children living in households that do not receive remittances and with at least one member who is an international migrant will have lower probabilities of staying out of the labor market and in school.

3. As their own mobility may disrupt the dynamics of the family and the educational trajectory of children who moved from the U.S. to Mexico, we may expect to find lower enrollment rates and higher labor participation among these migrant children. Nonetheless, the effect may vary depending on their circumstances in the U.S. Thus, children born in the U.S. to Mexican parents may be arriving back in Mexico with higher educational assets and motivations and, therefore may stay longer in school and out of the labor market. 
4. We expect to find that other immigrants (coming not from the U.S. but from other countries) will have the greatest disadvantages integrating into-or even having access to-the Mexican educational system.

5. All these effects will be mediated by the family arrangement. For example, the potential for positive gains for those receiving remittances may decrease when both parents are absent. Among immigrant children, we may find that those living with both parents are able to stay longer in school and not have to work.

6. Finally, as prior research has found, we expect that the migration experience at the community level may be also influencing the consumption, labor and educational expectations of adolescents. Thus, when living in communities with a higher prevalence of migration, there may be disincentives against staying longer in school-especially among those who have not been in the United States.

Transitions into the labor force are gendered in Mexico (boys tend to enter the labor market earlier and more often than girls; a large proportion of the girls not studying will be concentrated in domestic work). Furthermore, expectations from migration and education also differ. Prior research has suggested that there may be more pressure for adolescent men to migrate (as a rite of passage) than there is among women (Reichert, 1982 cited in Massey et al., 1993). In addition, the absence of the father or the mother affects boys and girls differently (Giorguli, 2004). Thus, we can expect that the effects may vary in magnitude and significance (but not in direction) between adolescent men and women. For this reason, we conducted our analysis stratified by sex.

\section{Data and methods}

The microdata of the 2010 Mexican Census Sample allow us to classify the population under 19 years of age in 6 categories, according to their migration experience: 1) no exposure to international migration, 2) children living in a household with migrants (circular or return migrants) $)^{1}, 3$ ) children living in a household receiving remittances, 4) children born in the U.S. living in Mexico with at least one parent born in Mexico, 5) return migrants, 6) circular migrants, and 7) other immigrants. First, we estimate the size of these populations and explore the distributions of their basic

As defined by the Mexican Census, return migrants had lived in the U.S. five years before the census year and were living in Mexico when the information was collected; circular migrants might have made one or more trips within the five years prior to the census year. This is a rough way of distinguishing between a short-term migration (circular) versus a migration that may have implied a longer period of stay in the U.S. 
sociodemographic characteristics in terms of age (categorical variable according to schooling age groups), gender, place of residence (divided into four categories according to population sizes), and their residential status relative to their parents. Using multinomial logistic regression models, we analyze the differences in the probabilities of only studying versus only working, studying or working, or neither of these activities, for adolescents 12 to 18 years old depending on their exposure to international migration, by sex. In these models, we control through the effect of the socioeconomic status and cultural capital of the household (household head's years of schooling) and the place of residence. ${ }^{2}$ We also include a migration prevalence index, which captures the proportion of households with migration experience in a municipality, and the family arrangement, which is a categorical variable that combines the relationship to the head of the household and the status of parental residence. To further capture how family arrangements mediate the interaction between international migration and the enrollment and labor status of children, we estimate separate models for different family arrangements.

\section{International migration exposure and participation of Mexican children and youth}

The Mexican census data allow us to analyze the exposure of children and youth to migration in several forms: they may have migrated to the U.S. or because they live in contexts that include experience of migration (they live in households that receive remittances or where a family member has migrated, or in communities with a prevalence of migration).

Table 1 shows the distribution of the Mexican population under 19 years of age grouped by their exposure to international migration. In 2010, $6.5 \%$ of the children and youth living in Mexico had some exposure to family migration or had been migrants themselves. This proportion represented 2.7 million minors. A large majority, about 1.4 million, lived in households that were receiving remittances and another 645 thousand were in households with experience of migration to the U.S. These two groups refer to children who did not move. The proportion living in rural and small urban areas was larger than the national average, which is consistent with the larger prevalence of international migration in these settings. More than 20\%

2 The models were run in two stages due to multicollinearity issues: one considering if there is any migrant in the household, and the other introducing the reception of remittances. The probabilities presented in Table 5 were estimated with the models of remittance reception -excluding the other household migration experience that was estimated with its own model-because systematically they had a better goodness of fit. We used the mean values of all the variables considered in the model to estimate the probabilities. 
(close to $30 \%$ in the case of those in households receiving remittances) lived in municipalities with a high prevalence of migration.

The third largest group is that of children born in the U.S. but whose parents are Mexican. This group represents close to 600,000 minors. Over half a million were born in the U.S. and lived with a least one parent born in Mexico, and around 310,000 had immigrated back to Mexico during the last five years. In most cases, we can expect that their migration would be linked to the return of one or both of their parents. They are younger than the other groups ( $83 \%$ are less than 12 years old) and most of them live in large urban or metropolitan areas of the country. More than $45 \%$ of these children live in border states, which may suggest some "womb migration", that is, mothers living on the border who give birth in the U.S. and then return to their hometowns. It might also reflect a pattern of forced return migration by their parents who, after living in the U.S. for a long period of time, have lost any connection to their places of origin and stay on the border, possibly even waiting in the expectation of eventually returning to the U.S. The available data do not allow us to explore these hypotheses, but the question remains as a topic to be developed in the future. Although there is a large concentration on the border, close to a third of U.S. born Mexican children live ${ }^{3}$ in a region that has the tradition historically of migration to the U.S.

Mexican children who are return or circular migrants themselves have a different sociodemographic profile. There is still a large concentration in young ages (below 12), but there are also more teenagers in comparison with the other groups. For circular migrants, the sex ratio is less balanced than for the other groups. In this case, we may think that for a group of these children-at least for some of them in their teens-their migration experience in the U.S. may be linked to their own labor experience and the search of job opportunities for themselves. There is also an important proportion of Mexican migrant minors living in border states (close to one third for return and for circular migrants) and in states with a large tradition of international migration to the US.

The last group we analyzed is that of immigrants from other countries. This is a small group and most of them were born in the U.S. and their parents are also American. The second largest group among them is that of children born in Central America. Immigration is mainly an urban phenomenon: $87 \%$ live in metropolitan or large urban areas and mostly in municipalities with a very low prevalence of migration to the U.S.

2 These children are American as they were born in U.S., but also have the right to have Mexican nationality as one of their parents is Mexican. We can also refer to them as dual citizens. 
In all cases of migrant children, the results from the 2010 Census show a large increase in comparison to the year 2000. This is an unexplored phenomenon that implies new challenges and demands policies to respond to the special needs of these children. We need to investigate in detail how and why they transit between countries and the risks associated with their moves, their conditions upon arriving in Mexico and their special needs in order to integrate successfully to the contexts of their destinations-starting with their access to social programs and their incorporation into the school system.

\section{Parental and family arrangements of children by migration experience}

As previously mentioned, the migration of children or other members of the family is related to a change in the organization of the family. Furthermore, the ways families are organized after the migration has occurred may also tell us something about the move itself. Table 2 shows the distribution of all migrant children subpopulations based on their status of co-residence with their parents and on their relation to the head of the household. In Mexico, most children live with both parents (more than $75 \%$ ) and the most prevalent arrangement is that of a nuclear household with both parents living in the same household (67\%). For children exposed to international migration, the distribution is different. For example, in households receiving remittances only $30 \%$ of the children live with both parents in a nuclear household. A large proportion live only with their mothers; most of them in independent households (27.3\%) and some others with grandparents (5.7\%). In this group, we see the largest proportion of cases where both parents are absent (16\%); these would be most of the cases of the "doughnut households" that we mentioned in a previous section. For these children, the international migration of adults-presumably mostly by their fathers and, to a less extent, their mothers-radically changes the arrangement of the household. It remains to be tested whether the monetary resources sent from the U.S. compensate for other aspects that may affect the educational trajectory of the child such as distress related to the family separation or changes in adult supervision of their school performance.

For all cases of children who migrate, more than $60 \%$ live with both parents and mainly in nuclear households. This figure suggests that, for most of these children, their migration is linked to the migration of their parents. The second largest arrangement is that of single parent households where only the mother is present and, for children born in the U.S., an important proportion (10\%) are living with their mother only, in extended households-mostly with their grandparents. One in every five of the children born in the U.S. live with their grandparents; grandparents may be 


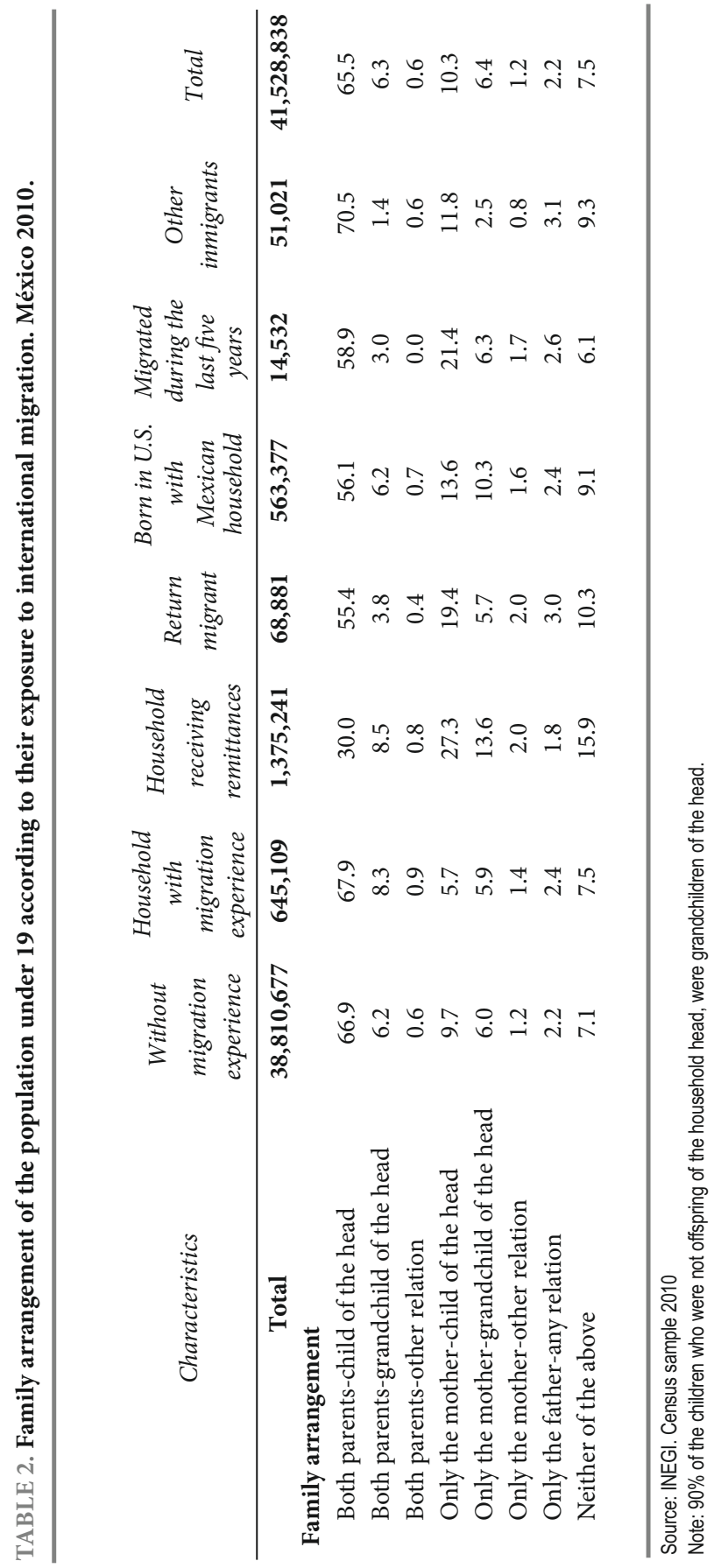


playing an important role for children born in the U.S., and especially for those living only with their mothers.

International migration and school enrollment and working status of the youth in Mexico

In this section, we explore the combinations between attending school and working, for adolescents 12 to 18 years of age living in Mexico in 2010, and the probabilities of falling into these categories depending on the teenagers' exposure to international migration. This group of adolescents includes two important schooling age groups: those attending 7 th to 9 th grade (secundaria) and those attending 10th to 12th grade (media superior). The former is part of compulsory education in Mexico, therefore almost $90 \%$ of teenagers were attending school ("only studying" and "studyingworking" groups), while for the latter, which was not mandatory in $2010^{4}$, school attendance barely accounted for $55 \%$ (see Table 3 ). Evidence of dropping out of school (either definitively or temporarily) after the 9th grade is clearly seen when comparing the percentages of teenagers fully dedicated to the labor market: 1 in every 5 adolescents aged 16 to 18 years was working, while the number of those under 16 years in this situation fell to below $4 \%$. Also, the proportion of teenagers neither working nor studying at the time of the census is significantly higher for those aged 16 to 18 , with the percentage for this group 15\% higher. It is important to consider that these children might be waiting to transition either between school levels (secundaria to preparatoria, roughly equivalent to secondary and high school) or between school and work. There is also an important gender story behind the figures, as we mentioned before, with boys entering the labor market earlier, while girls not studying will be

TABLE 3. Labor and school enrollment status of of the population 12 to 18 years old. México 2010.

\begin{tabular}{lrrr} 
Labor-enrollment status & 12 to 15 & 16 to 18 & Total \\
\hline Total & $8,748,593$ & $6,758,497$ & $15,507,090$ \\
Only studying & 85.3 & 50.8 & 70.3 \\
Only working & 3.5 & 20.7 & 11.0 \\
Studying-working & 2.8 & 4.9 & 3.7 \\
Neither of the above & 8.3 & 23.5 & 14.9
\end{tabular}

Source: INEGI. Census sample 2010

4 In 2012, the education law changed to include the high school level as compulsory. 


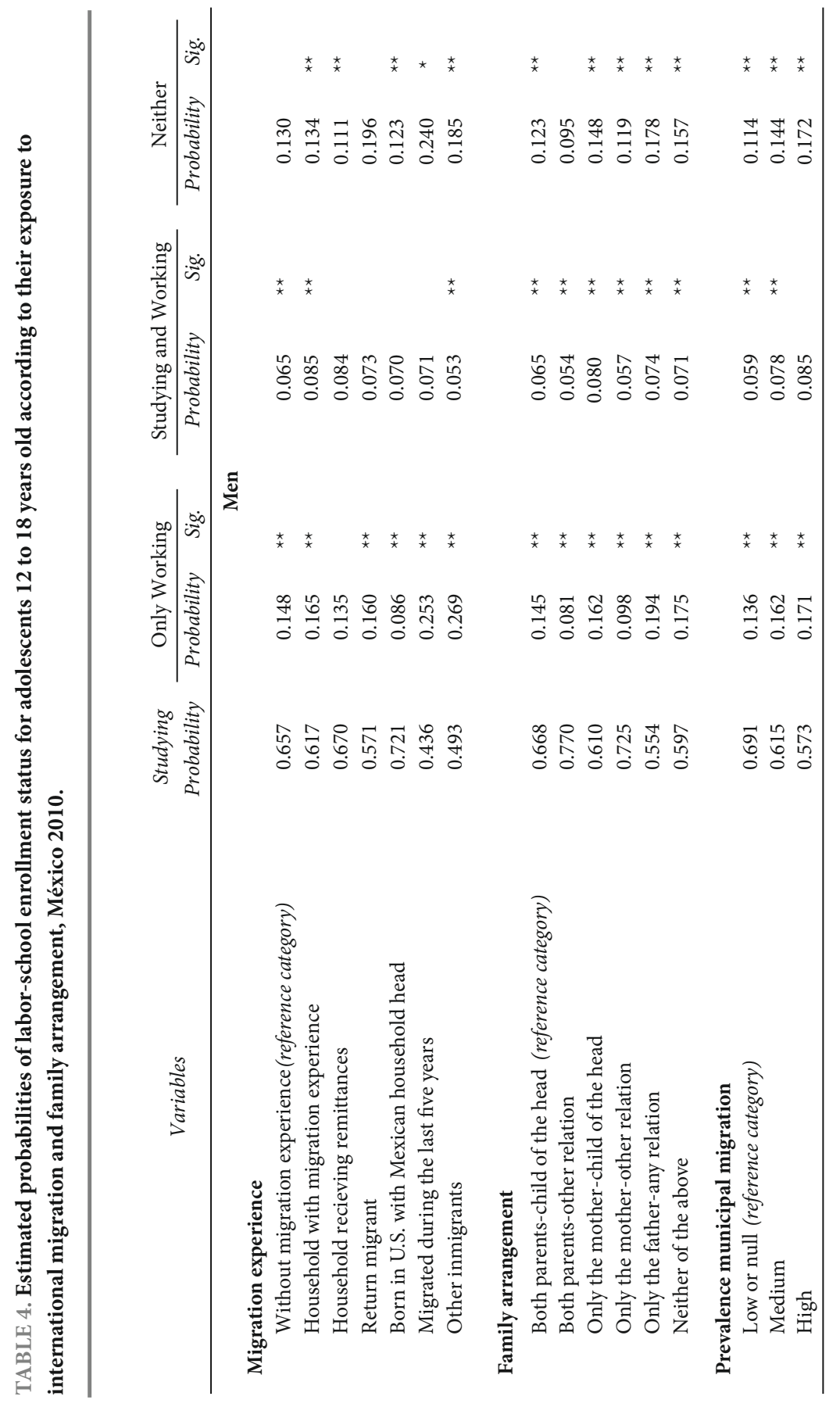




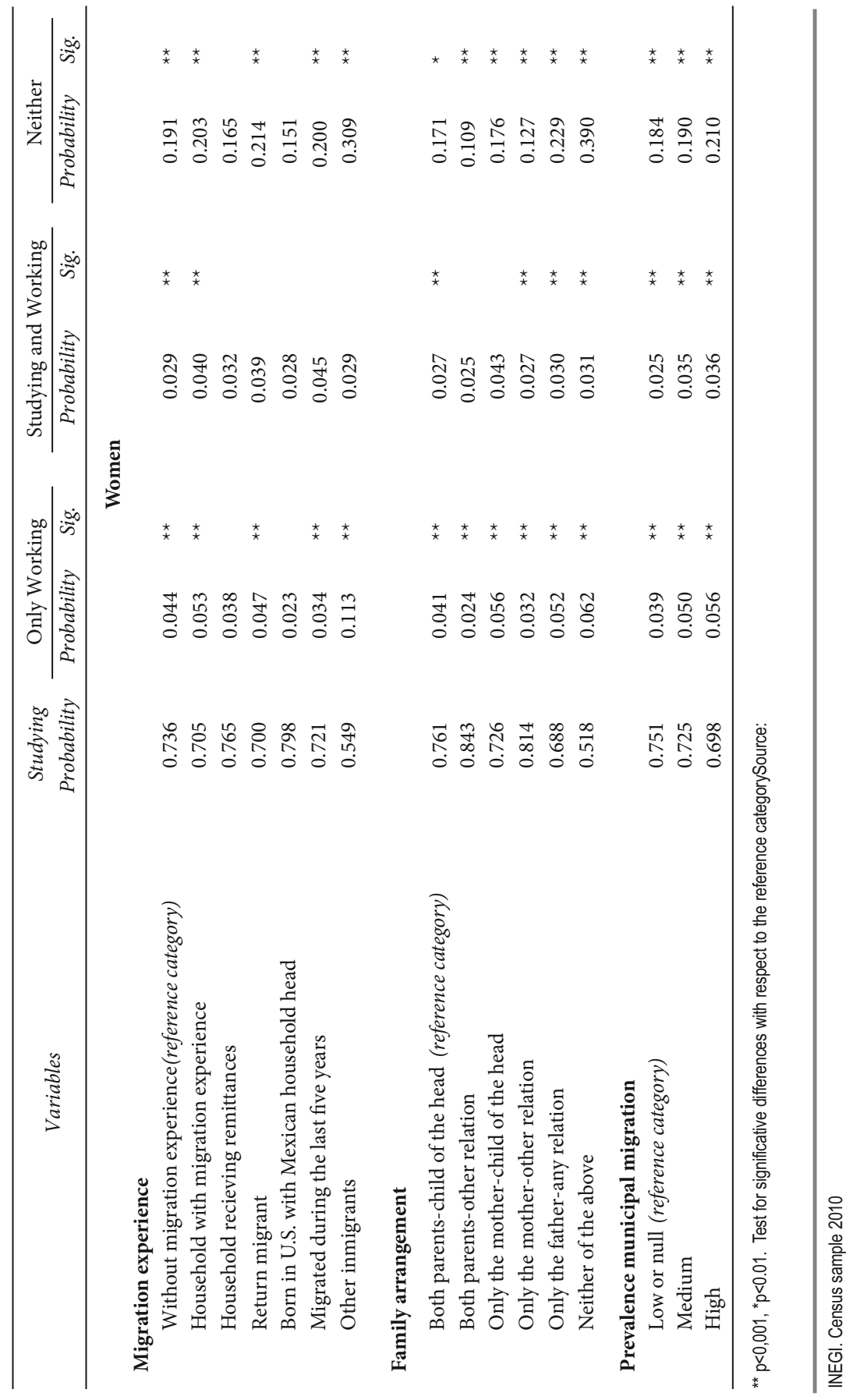


concentrated in domestic work. In 2010 two thirds of the 16 to 18 year old teenagers who neither work nor attend school were girls.

To understand how migration exposure shapes school attendance and labor force participation, we estimated probabilities of studying-working, only working and neither, compared to only studying for the teenagers in Mexico. Table 4 shows that the pattern of school attendance and labor participation varies among youth in Mexico according to their international migration experience. For both men and women, exposure to migration -either because a household member has migrated or because they live in the context of a medium or high prevalence of migration- is associated with lower school attendance. By contrast, if the household receives remittances, the probability of school attendance is slightly higher compared to that for youth without any exposure to migration.

For teenagers who had migrated to Mexico, there is a significant difference depending on the place of their birth. Those born in the United States clearly continue their educational careers and, indeed, are the group with the highest probabilities of staying in school without working and the lowest probabilities of "only working". This result is consistent both for men and women. In contrast, those born in Mexico who returned or who migrated to the United States in recent years have lower probabilities of staying in education, and the lowest are observed among other immigrants. For the latter, these have the highest probabilities of only working, for both men and women, and of neither working nor studying for women. Clearly, for immigrants whose parents are not Mexican citizens, migration implies the transition of leaving school, nonetheless, given their youth, they need special attention and support in the process of educational incorporation.

Our results also demonstrate that both migration and labor-school enrolment are highly gendered processes. Comparing the results in Table 4, women have systematically higher probabilities than men of only studying, while men are most likely to be working, either by being only in the labor market or combining school and work. However, women also show the highest probabilities, regardless of their migration experience, of being out of school or work, which reinforces previous findings of women leaving school to perform reproduction work at early ages. This situation is of greatest concern in the case of immigrant girls whose parents are immigrants as well, for whom these probabilities reach $30 \%$. We need to further study the conditions of this population to guarantee both their right to education as well as to have decent jobs. 
Parental co-residence as an intermediate factor in the link between international migration and the school/labor status of young people in Mexico

Finally, in this section, we explore how family arrangements interact with migration experience to shape the ways both factors are associated with educational attainmentlabor participation. Migration, as it implies the movement of one or more family members, directly transforms the living arrangements of families and their organization in terms of decision-making, budgeting or labor force participation. In addition, depending on which family member migrates and their role in the family (father, mother, sibling, etc.), we observe different experiences related to migration (probabilities of returning, sending money, etc.). In Table 5, we present tests of the differences between the coefficients of separate models of migration experiences for each family arrangement predicting the probabilities of educational attainment-labor participation by sex. Bolded coefficients indicate significant differences with respect to the full model (model of Table 4), in which "family arrangements" was included as a control variable. Some of our cells were not large enough to guarantee good estimates, and these coefficients are marked in gray; we would advise against interpreting them.

In Table 5 we observe that, within each family arrangement, experience of migration tends to decrease the probabilities of only studying versus other education-labor statuses, in comparison to teens with no migration experience, as at least half of the coefficients are positive across all columns for both men and women. In contrast, and systematically for all family arrangements, boys and girls born in the U.S. of Mexican parents have significantly lower probabilities of not being enrolled in school.

The benefits of remittances for increasing educational attainment (only studying and also studying-working) are strong and significant when the father or both parents are absent from the household. These associations are stronger in magnitude for women, and greatest for the competing probabilities of only working vis-a-vis only studying. The variations found in the associations between remittances and education by family arrangement help with understanding this relationship in depth. Migrationeducation literature has systematically found inconclusive results, with some studies offering support for increased attainment, while others found the opposite (Meza \& Pederzini, 2009; Hanson \& Woodruff, 2003; Giorguli \& Serratos, 2009; Antman, 2012; Borraz, 2005; McKenzie \& Rapoport, 2006). Further research will need to consider aspects of the transnational reorganizations of the family, especially which member of the family migrates, and the influence of these reorganizations on the social and economic lives of families in the place of origin. 


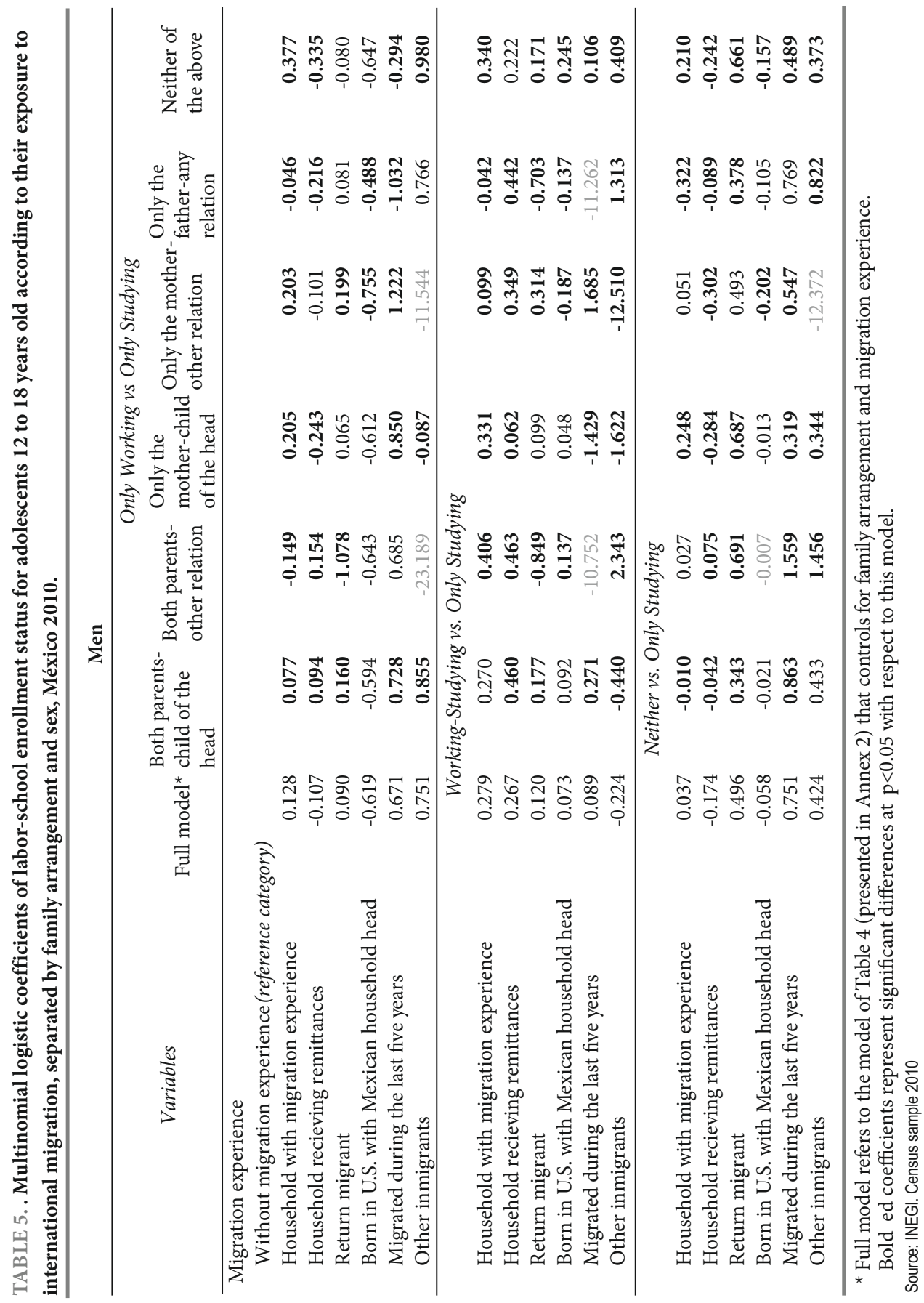




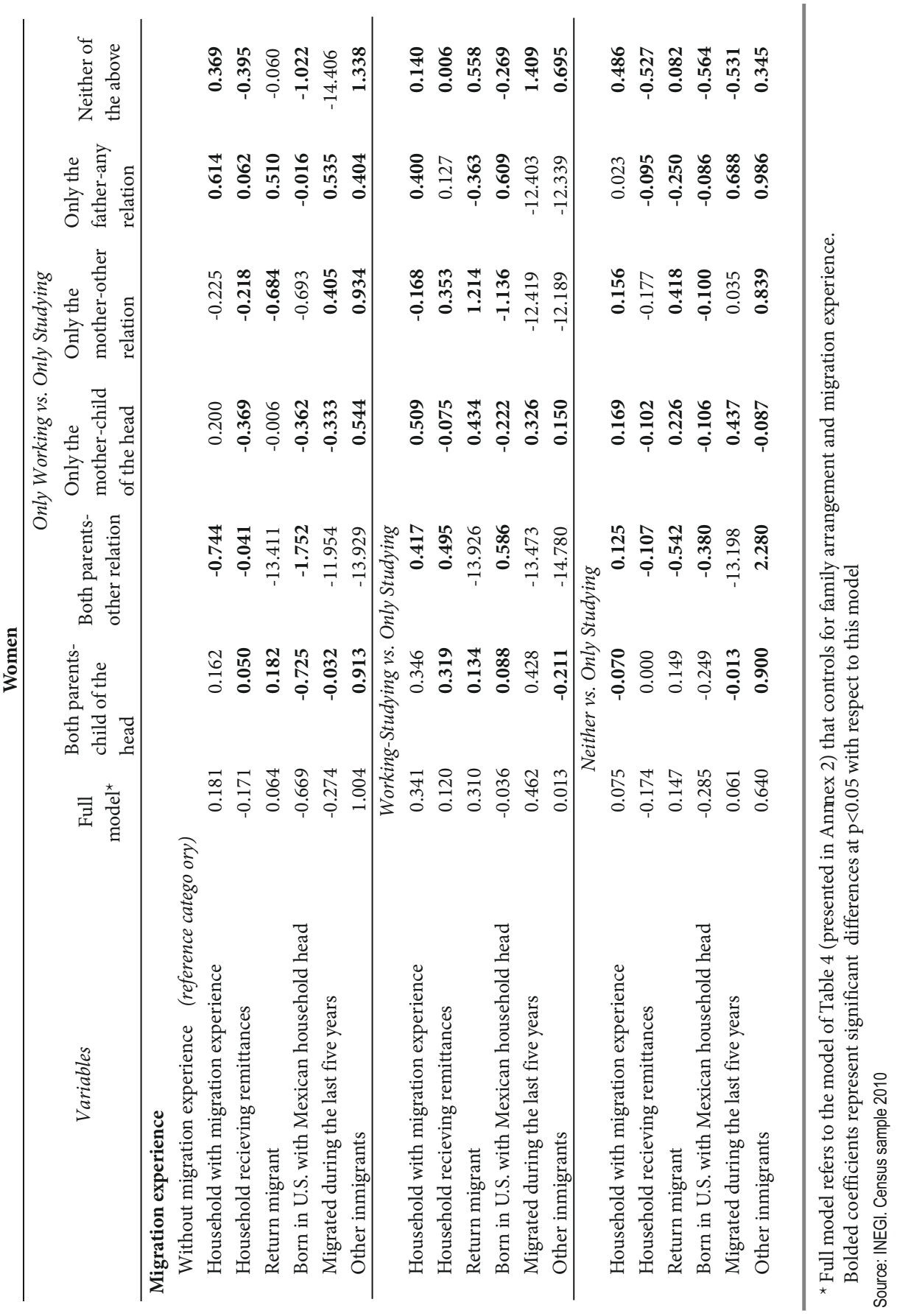




\section{Concluding remarks}

Our results indicate that Mexico-U.S. international migration affects the lifestyle of children with experience of it who are living in Mexico. They also highlight the participation of minors in the flows between the two countries and stress the need to consider the challenges that international migration represents for the Mexican Educational System in the context of returned flows and immigration to Mexico of children from the United States.

An additional finding is that the probabilities of staying enrolled and delaying entry into the labor market linked to international migration are mediated by parental co-residence with the children and by the place of residence (rural or urban). To a large extent, the absence of one parent may be related to some loss of financial security, and of adult supervision of school work. The loss of social capital may have a negative impact on a child's educational trajectory. Our results suggest that the absence of the mother may have a more detrimental effect on children's enrollment, the absence of the father might be compensated for though just in economical terms with remittances, and the presence of grandparents may also reduce the negative impact of parental separation.

Finally, there seem to be variations in the link between education and international migration according to setting (rural or urban). In rural settings, children who remain behind face a more disadvantaged context, with lower educational opportunities and lower quality schools. This may discourage children from staying in school and may also have a negative impact on achievement, which may be reflected in dropping out early.

Further research needs to consider a multidimensional and intersectional approach, which is one that looks at different dimensions of the link between education and international migration, and most importantly that recognizes and considers the interactions between these dimensions to flesh out better the web of relations shaped by migration itself. The need for these new approaches and frameworks when addressed will help improve the definition of policy recommendations on topics such as the incorporation and retention of migrant teenagers in the education system.

\section{References}

Antman, F. (2012). The impact of migration on family left behind. In Constant, A. \& Zimmermann, F. (Eds.), International handbook on the economics of migration, 
(pp. 293-308). Cheltenham, UK, Northampton: Edward Elgar Publising. Arias, P. (2013). Migración, economía campesina y ciclo de desarrollo doméstico. Discusiones y estudios recientes. Estudios Demográficos y Urbanos, 28(1): 93-121. Ariza, M. \& D'Aubeterre, M. E. (2009). Contigo en la distancia. Dimensiones de la conyugalidad en migrantes mexicanos internos e internacionales. In Rabell, C. (coord.), Tramas familiares en el México contemporáneo (pp. 353-394). Mexico City: Instituto de Investigaciones Sociales-UNAM, El Colegio de México.

Borraz, F. (2005). Assessing the impact of remittances on Schooling: the Mexican experience. Global Economy Journal, 5(1), 1-30.

Canales, A. \& Montiel, I. (2004). Remesas e inversión productiva en comunidades de alta migración a Estados Unidos. El caso de Teocaltiche, Jalisco. Migraciones Internacionales, 2(2), 142-172.

Castillo, Manuel Ángel (2012), “Extranjeros en México, 2000-2010”, in Coyuntura Demográfica, núm. 2, pp. 57-61.

Giorguli, S. (2004). Transitions from school to work: educational outcomes, adolescent labor and families in Mexico. PhD dissertation, Brown University. Providence, Rhode Island.

Giorguli, S. (2006). La migración a Estados Unidos desde la perspectiva de las comunidades de origen. Reflexiones en torno a su impacto social. In Zúñiga Herrera, E., Arroyo Alejandre, J., Escobar Latapí, A \& Verduzco Igartúa, G. (coords.), Migración México-Estados Unidos. Implicaciones para ambos países (pp. 155-170). México: Consejo Nacional de Población, Universidad de Guadalajara, CIESAS, Casa Juan Pablos, El Colegio de México.

Giorguli, S. \& Gutiérrez, E. (2011). Niños y jóvenes en el contexto de la migración internacional entre México y Estados Unidos. Coyuntura Demográfica, 1, 21-25.

Giorguli, S. y Serratos, I. (2009). El impacto de la migración internacional sobre la asistencia escolar en México: ¿paradojas de la migración. In Leite, P. \& Giorguli, S. (coords.), El estado de la migración. Las políticas públicas ante los retos de la migración mexicana a Estados Unidos (pp. 313-344). México: Consejo Nacional de Población.

Giorguli, S., Vargas, E., Salinas, V., Hubert, C. \& Potter, J. (2010). La dinámica demográfica y la desigualdad educativa en México. Estudios Demográficos y Urbanos, 25(1), 7-44.

Giorguli, S. \& Gutiérrez, E. (2011). Niños y jóvenes en el contexto de la migración internacional entre México y Estados Unidos. Coyuntura Demográfica, 1, 21-25.

Giorguli, S. \& Gutiérrez (2012). Migration et développement. De l'ambivalence à la désillusion? Hommes et Migrations, 1296, 22-33. 
Giorguli Saucedo, S. E., Vargas Valle, E. D., Ulloa, V. S., Hubert, C., \& Potter, J. E. (2010). La dinámica demográfica y la desigualdad educativa en México. Estudios Demograficos y Urbanos, 25(1), 7-44.

Gutiérrez, E., Sánchez, L. \& Giorguli, S. (2011). Accounting for spatial heterogeneity in educational outcomes and international migration in Mexico. Computational Science and its Applications ICCSA 2011. International Conference, Santander, Spain, June 20-23, 2011. Proceedings, Part I, 192-206.

Hanson, G. \& Woodruff, C. (2003). Emigration and educational attainment in Mexico. Working paper. Retrieved from http://www.childmigration.net/files/Hanson_2003.pdf

Massey, D., Arango, J., Hugo, G., Kouaouci, A., Pellegrino, A. \& Taylor, E. (1993). Theories of international migration: a review and appraisal. Population and Development Review, 19(3), 431-466.

Hondagneu-Sotelo, P. (1994). Gendered transitions: Mexican experiences of immigration. University of California Press.

Kandel, W. \& Massey, D. S. (2002). The culture of Mexican migration: a theoretical and empirical analysis. Social Forces, 80(3), 981-1004.

López Castro G. (2007). Migración, mujeres y salud emocional. Decisio, SeptemberDecember, 46-50.

McKenzie, D. \& Rapoport, H. (2006). Can migration reduce educational attainment? Evidence from Mexico. World Bank Policy Research Working Paper 3952.

Meza, L. \& Pederzini, C. (2009). Migración internacional y escolaridad como medios alternativos de movilidad social: el caso de México. Estudios Económicos Special Issue, 163-206.

Oehmichen, C. (2000). Las mujeres indígenas migrantes en la comunidad extraterritorial. In Barrera Bassols, D. \& Oehmichen Bazán, C. (eds,), Migración y relaciones de género en México (pp. 319-349). México: GIMTRAP-UNAM/IIA.

Reichert, J. (1982). Social stratification in a Mexican sending community: the effect of migration to the United States. Social Problems, 29, 422-433.

Sánchez, J. \& Zúñiga, V. (2010). Trayectorias de los alumnos transnacionales en México. Propuesta intercultural de atención educativa. Trayectorias, 12(30), 5-23.

Zenteno, R. (2012). Saldo migratorio nulo: el retorno y la política anti-inmigrante. Coyuntura Demográfica, 2, 17-21. 
ANNEX 1. Descriptive statistics of selected sociodemographic variables of teenagers 12 to 18 years old, México 2010.

\begin{tabular}{|c|c|c|}
\hline \multirow{2}{*}{ Variables } & \multicolumn{2}{|c|}{ Mean or distribution } \\
\hline & Men & Women \\
\hline \multicolumn{3}{|l|}{ Migration experience } \\
\hline Without migration experience (reference category) & 0.923 & 0.918 \\
\hline Household with migration experience & 0.018 & 0.019 \\
\hline Household recieving remittances & 0.050 & 0.053 \\
\hline Return migrant & 0.002 & 0.002 \\
\hline Born in U.S. with Mexican household head & 0.006 & 0.007 \\
\hline Migrated during the last five years & 0.001 & 0.000 \\
\hline Other inmigrants & 0.001 & 0.001 \\
\hline \multicolumn{3}{|l|}{ Family arrangement } \\
\hline Both parents-child of the head & 0.706 & 0.676 \\
\hline Both parents-other relation & 0.020 & 0.020 \\
\hline Only the mother-child of the head & 0.131 & 0.129 \\
\hline Only the mother-other relation & 0.034 & 0.034 \\
\hline Only the father-any relation & 0.028 & 0.023 \\
\hline Neither of the above & 0.081 & 0.118 \\
\hline \multicolumn{3}{|l|}{ Prevalence municipal migration } \\
\hline Low or null (reference category) & 0.604 & 0.600 \\
\hline Medium & 0.249 & 0.249 \\
\hline High & 0.147 & 0.151 \\
\hline Age & 14.966 & 14.929 \\
\hline Household head years of schooling & 6.237 & 6.253 \\
\hline \multicolumn{3}{|l|}{ Place of residence } \\
\hline Less than $15000 \mathrm{hab}$ & 0.346 & 0.345 \\
\hline 15000 a 99999 hab & 0.322 & 0.321 \\
\hline 100000 and more habitants & 0.179 & 0.179 \\
\hline Metropolitan area & 0.153 & 0.154 \\
\hline
\end{tabular}

Source: INEGI. Census sample 2010 


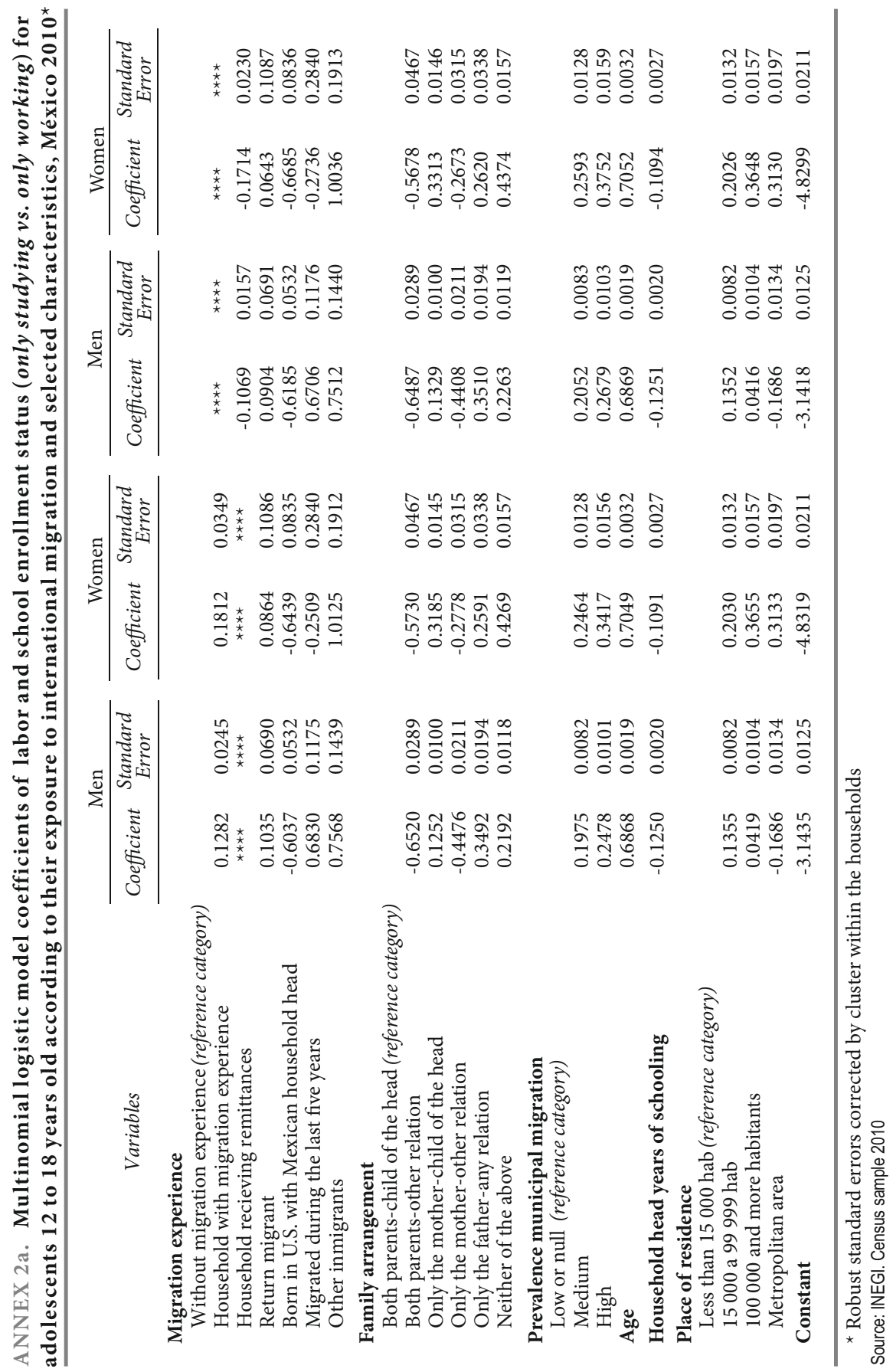




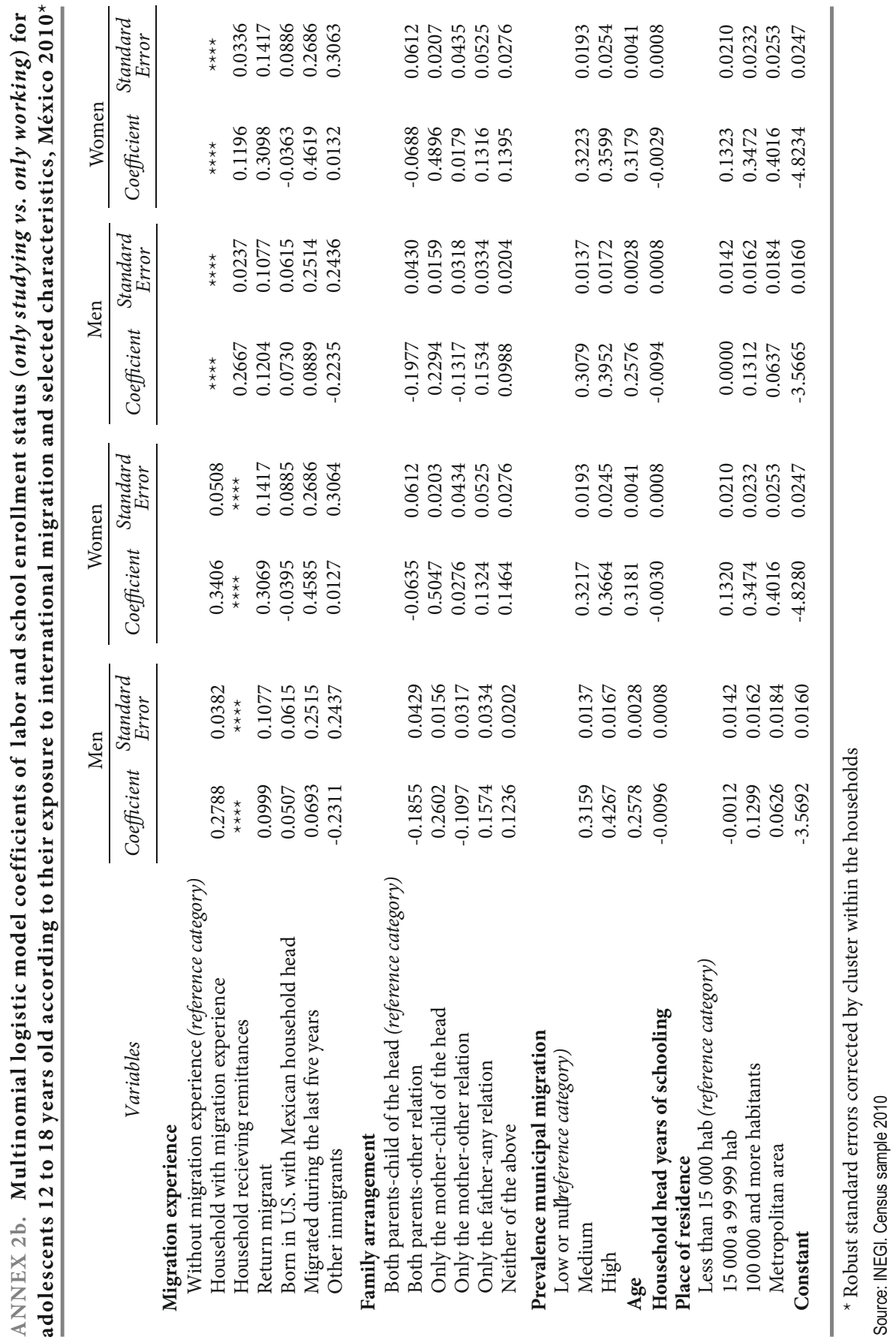




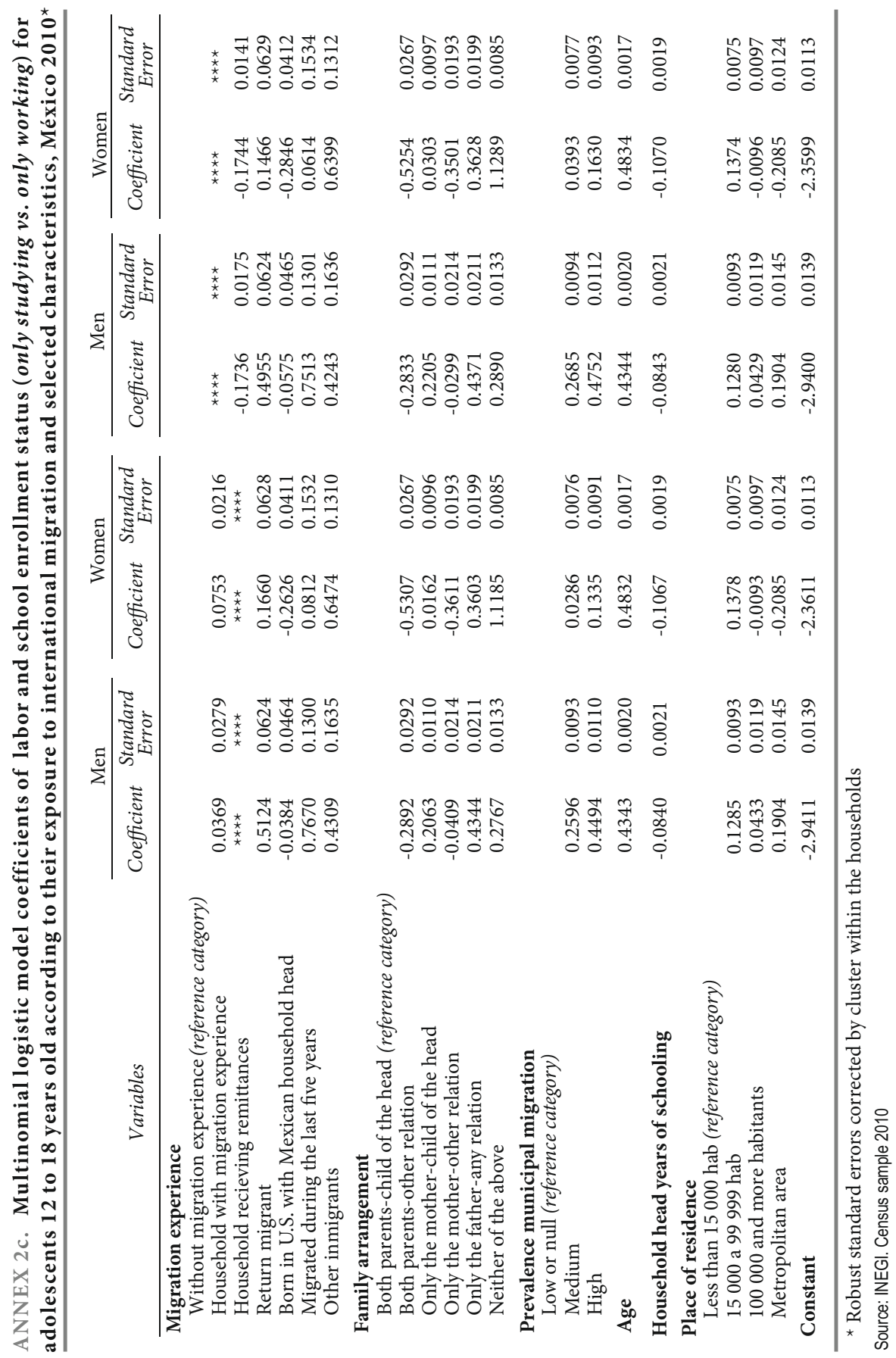

